\title{
EMOTIONS TOWARDS PHYSICAL EDUCATION LESSONS OF HEARING IMPAIRMENTS PUPILS ATTENDING SPECIAL ELEMENTARY SCHOOLS
}

\author{
Dagmar Nemček ${ }^{1}$, Stanislav Kraček ${ }^{1}$, Petra Kurková ${ }^{2}$ \\ ${ }^{1}$ Faculty of Physical Education and Sports, Comenius University in Bratislava, Slovakia \\ ${ }^{2}$ Faculty of Education, Palacký University in Olomouc, Czech Republic
}

Summary: The purpose of this study was to map and analyse the emotions among the pupils attending special schools for children with hearing impairments (HI) towards physical education (P.E.) classes. The main objective was to compare the emotions of their feelings during the P.E. lesson and when the P.E. lesson is cancelled. We analysed the data of 73 pupils attending five grades (from $5^{\text {th }}$ up to $9^{\text {th }}$ ) of two special elementary schools (at Hrdličkova Street; $n=37$ and at Drotárska cesta Street; $n=36$ ) in Bratislava (Slovakia). The research sample consisted of 45 boys and 28 girls in average age $13.5 \pm 1.4$ years. $48 \%$ of pupils were deaf, $36 \%$ of them were hard of hearing and $16 \%$ were hearing but with hard communication and learning disorders. A non-standardized questionnaire (Antala et al. 2012) was used as a primary research method. Two of the selected questions were related to the emotionality towards P.E.lessons. The data were differentiated from the point of view of the gender and schools. A comparison of the emotions of pupils with HI pointed out a difference consisting in a significantly higher level of positive emotions during P.E. classes among boys $(p<.05)$ and students attending special school at Hrdličkova Street $(\mathrm{p}<.05)$. A statistically significant difference was not discovered in the emotions when P.E. class was cancelled neither among genders nor schools. In general, pupils receiving special education show very high positive emotions of the feelings during P.E. lessons but on the other hand they are happier than disappointed when P.E. lesson is cancelled. This will not only increase the positive emotions towards P.E. lessons but also allow physical activities to become a regular part of pupils' leisure activities as well as long term sport activities.

Key words: physical education lessons, special education, deaf and hard of hearing, feelings, positive and negative emotions

DOI 10.2478/afepuc-2018-0007

(C) Acta Facultatis Educationis Physicae Universitatis Comenianae 


\section{Introduction}

The key factor that affects the success of shaping positive attitudes towards the regular life-long performance of a physical activity is the pupils' level of inner motivation. This is influenced, among other things, by their family background, the educational institution that they attend and the educator's competencies (Smoleňáková \& Bendíková 2017). Compulsory physical education (P.E.) classes can be considered as an integral part of their education, and the most effective form of physical activity (Gerhatová 2001; Bendíková 2014). An important precondition is the pupils having a subjective feeling of satisfaction, feeling of positive emotional reactions. A number of P.E. tasks and open-air sports have the potential for eliciting positive or negative emotional reactions, because of the physical and psychological challenges inherent in the activity (Robazza et al. 2006).

The significance of the feelings and emotions towards P.E. classes is known for a longer period. Sýkora (1988) speaks about the need to increase positive emotions and the attractiveness of P.E. lesson by tools such as exercise with music accompaniment, including competitions and games into P.E. lessons, clarifying meaning and way achieving goals, controlling and self-assessing the positive results and so on, as important factors of activation, stimulation and motivation. Since then, the situation has significantly changed in society and in education as well but the emotionality of P.E. classes is still a topical question. This is an important part of the process at a particular lesson, but as well it has a great meaning to create positive relation to movement, sport, and gain relationship to lifelong physical activity (Digelidis et al. 2003; Čillík 2012).

It is therefore essential to create at the P.E. classes the atmosphere of joy, emotions, that can significantly affect the quality of the course and the quality of educational process in general, but mainly interest and perspective relationship towards long-term physical activity (Biddle, Gorely \& Stensel 2004). Joy is the one of the most natural and the most pleasant emotions. It gives us a sense of satisfaction and therefore we try to focus our activities in such a way as to reach the results produced a sense of happiness and joy. Joy can be aroused e.g. good physical well-being and satisfaction of human organic needs. Joy is reflected not only in the physical status, in good activity of all human organs but, above all, lead to optimal bark excitability of brain hemispheres, so they also make mental work easier (Spray, Biddle \& Fox 1999). Positive emotions towards P.E. classes affect not only the effectiveness of the classes themselves, but also the course and quality of education in other teaching lessons. It is then 
important to accept such assumption, the meaning of emotionality of the P.E. classes is extensive, exceeding the scope of P.E. class itself and educational and teaching process at all kinds of schools including special schools.

Čillík (2012) in his study surveyed positive and negative emotions of pupils attending regular Slovak elementary schools by two questions that inspired us to find out the same emotions but in the group of pupils attending special elementary school for children with hearing impairments (HI). He found, that at P.E. classes predominate positive emotions. Primary school pupils feel positively at the P.E. lessons in $70.6 \%$ and only $4.4 \%$ of pupils attending regular Slovak schools displayed negative emotions. Approximately 2/3 pupils of primary and secondary school of his research feel at P.E. lessons always good or mostly always good. Emotions and feelings among pupils with different kinds of disabilities have already been investigated by Kurková, Nemček \& Labudová (2015). They found out that those pupils who are deaf and hard of hearing (D/HH) have a good feeling about them while in P.E. classes, but pupils with visual disabilities expressed having a higher evaluation of their feelings.

The results of Čillík's (2012) investigation show that with rising age, feelings at P.E. classes increasing negative emotions. He further found, that $30.4 \%$ of elementary school pupils enjoyed themselves when P.E. lesson is cancelled, $26.4 \%$ of pupils were indifferent about it and $43.1 \%$ of pupils of his survey were confused. For secondary school pupils was this ratio even higher, when $53.2 \%$ students were happy when P.E. was cancelled, $29.3 \%$ students were indifferent about it, and only $17.5 \%$ of students were irritated. The factors that cause this phenomenon are several and are necessary analyse them in more detailed, say author (Čillík 2012).

Another investigation of feelings and emotions towards P.E. classes at special schools was done by Kurková \& Nemček (2016) who have found out significant differences between the students with three different kinds of disabilities with regards to their opinions in the case that for some reason a regular P.E. lesson is cancelled. The happiest group in their study were the students with physical disabilities, those who are always happy (25.7\%) or happy very often (12.9\%) if a P.E. lesson is cancelled. Secondly the students with physical disabilities were followed by the students who are $\mathrm{D} / \mathrm{HH}$. The results of their research clearly showed that the students with visual disabilities expressed the highest degree of pity that a P.E. lesson was lost, in comparison with other students with disabilities, which can be supported by the very significant differences seen in the opinions expressed by different groups of students (Kurková \& Nemček 2016). The scientific work of other authors confirms the positive 
attitude and high popularity of P.E. classes (Görner \& Starší 2001; Antala \& Labudová 2008; Bartík 2009; Kurková 2010). The objective of this study is to analyse the emotions of pupils attending special elementary school for children with HI at the P.E. lessons and when a P.E. lesson is cancelled.

\section{Methods}

Participants

The research sample comprised 73 pupils attending five grades (from $5^{\text {th }}$ up to $9^{\text {th }}$ ) of two special elementary schools in Bratislava (Slovakia). The elementary boarding school for children with HI located in Hrdličkova Street was represented by 37 pupils and the elementary boarding school for children with HI located in Drotárska cesta Street was represented by 36 pupils. The research sample consisted of 45 boys and 28 girls in average age $13.5 \pm 1.4$ years. $48 \%$ of pupils were deaf, $36 \%$ of them were hard of hearing and $16 \%$ were hearing but had hard communication and learning disorders.

Pupils were informed of the purpose of the research and the procedure for filling out the questionnaire, which was to be completed in the presence of their head teacher and the researcher. At the schools we set up a procedure that ensured that pupils who are $\mathrm{D} / \mathrm{HH}$ and used sign language properly understood all the questions in the questionnaire. Upon previous agreement and explanation of the purpose of the questionnaire, the actual questions were signed by a teacher who had perfect command of sign language and to whom the pupils were familiar. We proceeded by asking each item individually and then fact-checking to make sure that the pupils individually understood the questions. Consent of the legal representatives of the pupils at both schools regarding the pupils' participation in the study was obtained well in advance.

\section{Data collection}

A non-standardized questionnaire (Antala et al. 2012) was used to collect the data, of which two questions were selected that were related to the feelings and emotions towards P.E. classes. These questions included the pupils' emotions: a) how they feel at the P.E. lesson (Question 1: I feel at the P.E. lesson: Always good, Mostly good, I don't care about it, Mostly bad, Always bad); b) how they feel, when a P.E. lesson is cancelled (Question 2: If a P.E. lesson is cancelled: I am always happy, I am often happy, I am indifferent about it, I usually get upset, I always get upset). In questions the pupils expressed their subjective opinions 
using a 5-degree scale. 1 was the highest level of positive emotions and 5 was the highest level of negative emotions.

\section{Data analysis}

Statistical analysis was undertaken using IBM SPSS version 23.0 for Windows. The data were differentiated from the point of view of the gender and schools. The data were quantified on mean and percentage basis. Pearson chi-square test was used to determine the differences between the groups. The level of statistical significance was set to $p<.05$.

\section{Results}

The results show mostly positive emotions towards P.E. lessons in pupils receiving special education when $19.2 \%$ are feeling at the P.E. always good and $38.4 \%$ of them mostly good. On the other hand only $10.9 \%$ of special schools pupils showed the negative emotions when $8.2 \%$ of them are feeling at the P.E. lessons mostly bad and $2.7 \%$ always bad.

The results show statistically significant difference in the emotions towards P.E. expressed by pupils' feeling at the P.E. lessons from the point of view of the respondents' gender $(\mathrm{p}<.05)$. Even though girls receiving the special education have a good feeling about themselves while in P.E. classes, boys expressed having a higher positive evaluation of their feelings (Figure 1). The cross-group comparison of the emotions towards P.E. among boys and girls attending special elementary schools for children with HI proved to be statistically important. This may serve as evidence of the suitability of the educational environment for boys; nevertheless, this result does not provide enough data to satisfactorily stipulate the quality of education and learning, i.e. the character of the topics taught and level of actual inclusion in class. 


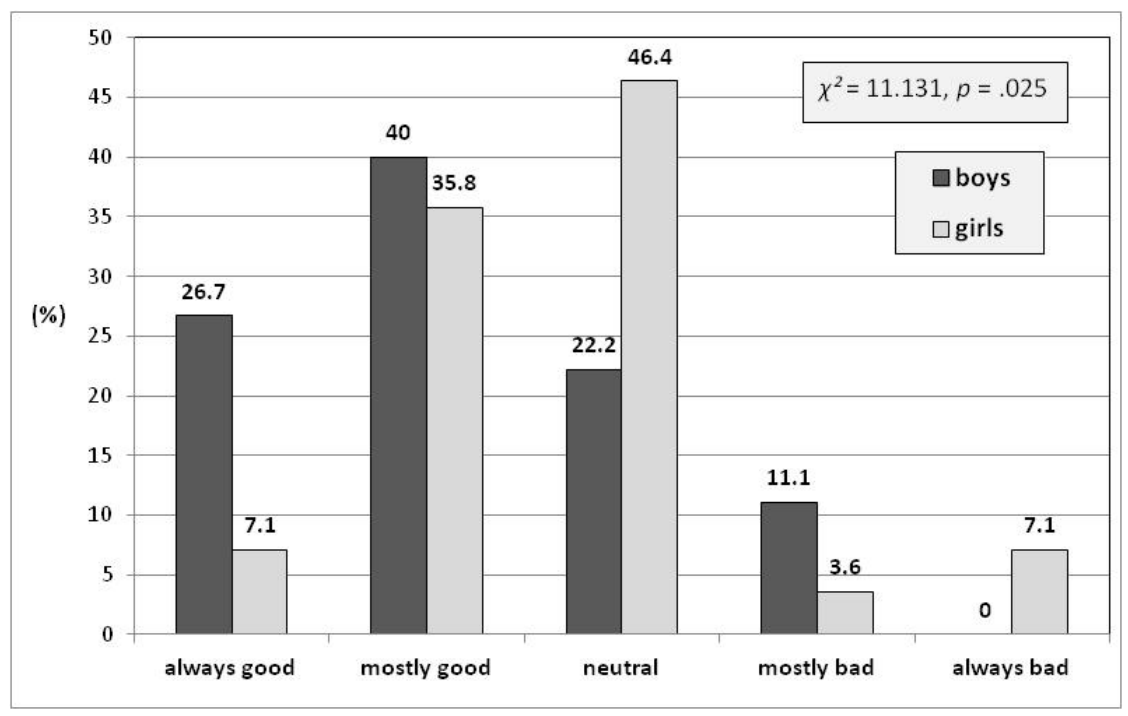

Figure 1

Feelings of pupils during P.E. lessons (gender comparison)

Having analysed emotions in pupils receiving special education we found out significant differences between two special schools for children with HI $(\mathrm{p}<.05)$. Even though pupils attending special elementary school at Drotárska cesta are feeling at P.E. lessons mostly good (50.0\%), pupils from special elementary school located in Hrdličkova Street expressed having a higher positive evaluation of their feelings, because $32.4 \%$ of them are feeling at P.E. lessons always good and $27.1 \%$ mostly good (Figure 2). Higher negative emotions were displayed by pupils from the special school located at Drotárska cesta $(16.7 \%)$ comparing expressed negative emotions of pupils from Hrdličkova Street special elementary school. Those pupils presented higher status of neutral emotions at P.E. lessons $(35.1 \%)$ than pupils receiving special education at Drotárska cesta $(27.7 \%)$.

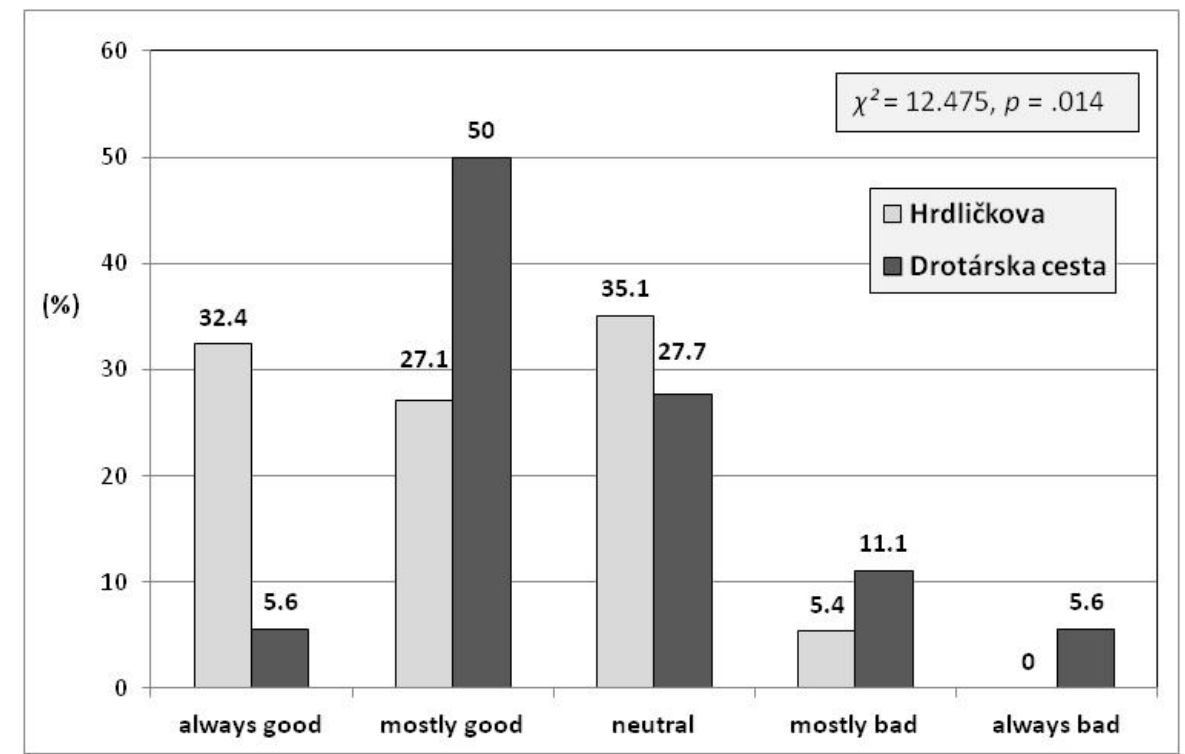




\section{Figure 2}

Feelings of pupils during P.E. lessons (school comparison)

The results further show the highest level of indifference in pupils receiving special education in the case that for some reason a regular P.E. lesson is cancelled. $50 \%$ of pupils attending two elementary special schools for children with HI expressed neutral emotions (by saying: "I don't care about it") if a P.E. lesson is cancelled. Answering this question, pupils presented higher level of positive emotions when $22.2 \%$ of them are happy very often and $16.7 \%$ were always happy when P.E. lesson is cancelled. Only $6.9 \%$ pupils were upset and $4.2 \%$ very upset if a P.E. lesson is cancelled.

There were no significant differences between boys and girls attending special schools with regards to their emotions in the case that for some reason a regular P.E. lesson is cancelled (Figure 3). Happier group were girls, who are happy very often (32.1\%) and always happy $(14.3 \%)$ if a P.E. lesson is cancelled. With regards to this kind of happiness, they are followed by boys, since $17.8 \%$ of them are always happy or happy very often $(15.6 \%)$. On the other hand, this group shows little bit higher level of indifference towards such a situation (51.1\%) comparing girls $(50.0 \%)$. Higher degree of negative emotions to a cancelled P.E. lesson was declared by boys, since $8.8 \%$ of them feel upset and $6.7 \%$ always upset if a P.E. lesson is cancelled.

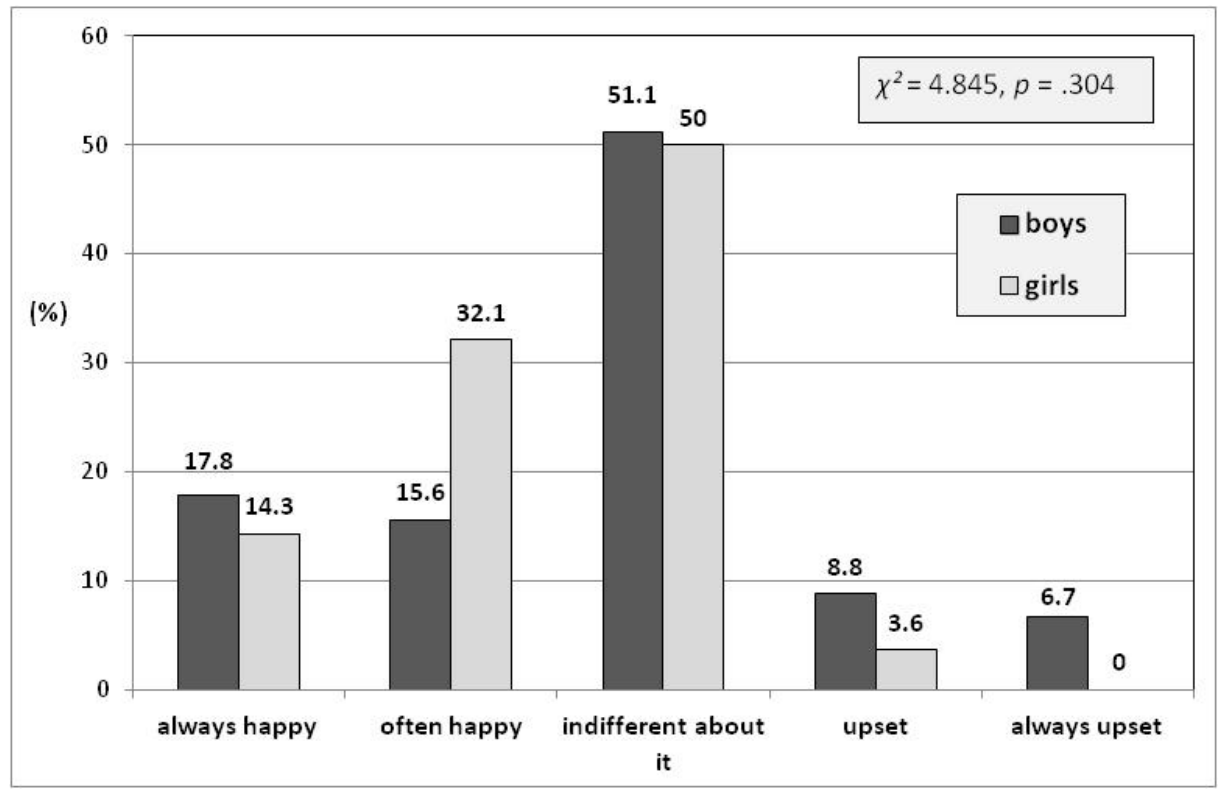

Figure 3

Reaction of pupils when a P.E. lesson is cancelled (gender comparison) 
Having evaluated emotions in pupils receiving special education we did not find significant differences between two special schools for children with HI with regards to their reaction when a P.E. lesson is cancelled. Even though pupils attending special elementary school at Drotárska cesta showing higher level of positive emotions when $30.6 \%$ are often happy and $16.7 \%$ always happy when a P.E. lesson is for some reason cancelled comparing pupils attending special school at Hrdličkova Street (Figure 4). Those pupils display higher level of indifference (56.8 \%) comparing pupils attending special school located at Drotárska cesta $(41.6 \%)$.

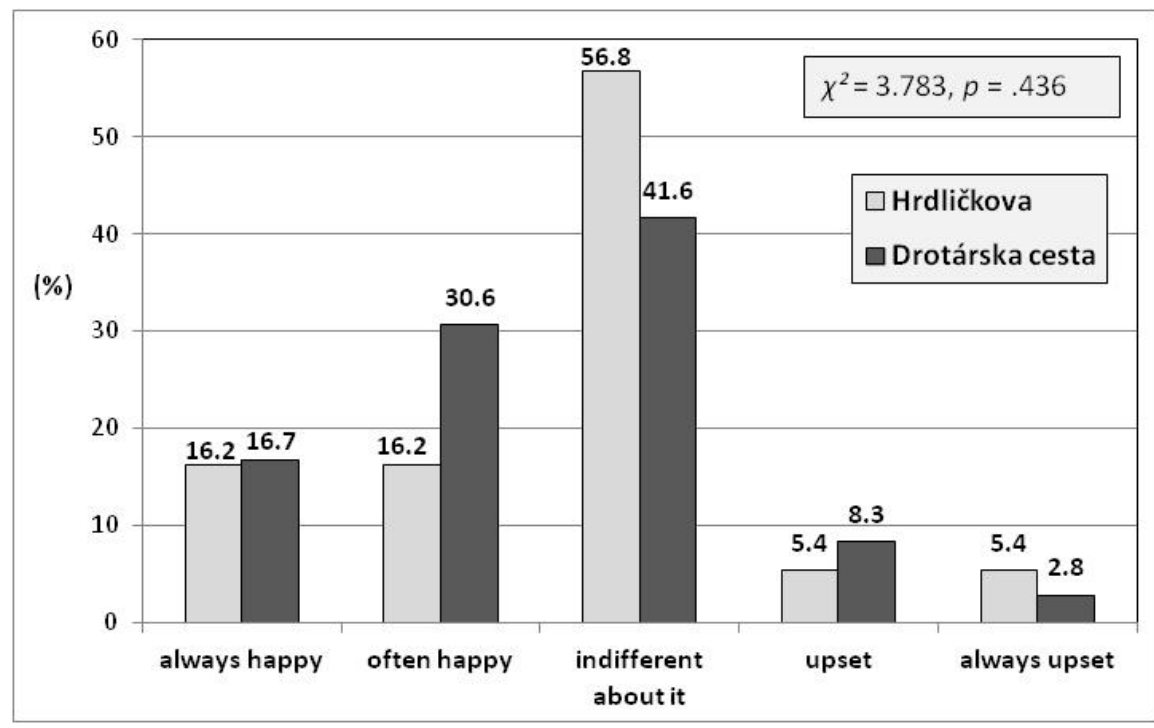

Figure 4

Reaction of pupils when a P.E. lesson is cancelled (school comparison)

By comparing the mean values of the responses provided by students attending special elementary schools for children with HI, higher level of positive emotions about feelings during P.E. classes was stated by boys (2.178 points of the mean score) as opposed to girls (2.678 of the point score) and pupils attending special school at Hrdličkova Street (2.054 points of the mean score) comparing pupils receiving special education at the school at Drotárska cesta Street (2.611 of the point score).

Evaluating the mean scores of the responses about their reactions when a P.E. lesson is cancelled, higher level of positive emotions was expressed by girls (2.429 points of the mean score) as opposed to boys (2.711 of the point score) and pupils attending special elementary school at Drotárska cesta (2.500 points of the mean score) comparing pupils receiving special education at the school at Hrdličkova Street (2.676 of the point score) (Table 1). 
Table 1

Mean score of emotions towards P.E. classes

\begin{tabular}{|c|c|c|c|c|}
\hline \multirow{2}{*}{ Question about } & \multicolumn{2}{|c|}{ Gender } & \multicolumn{2}{c|}{ School } \\
\cline { 2 - 5 } & Boys & Girls & Hrdličkova & Drotárska c. \\
\hline $\begin{array}{c}\text { Feelings of pupils during } \\
\text { P.E. lesson }\end{array}$ & 2.178 & 2.678 & 2.054 & 2.611 \\
\hline Total & & & & \\
\hline $\begin{array}{c}\text { Reaction of pupils when a } \\
\text { P.E. lesson is cancelled }\end{array}$ & 2.711 & 2.429 & 2.676 & 2.500 \\
\hline Total & & \multicolumn{3}{|c|}{2.597} \\
\hline
\end{tabular}

\section{Discussion}

Developing a habit of engaging in regular physical activity is a gradual and unforced process that must respect a pupil's physical readiness and interests. Those findings were supported by research studies conducted by Nagyová (1995) and also Novotná, Kariková \& Vladovičová (2007). Those studies proved that there are both various positive and negative emotions that affect pupils in P.E. class.

The aim of this study was to map the feelings and emotions of $5^{\text {th }}$ up to $9^{\text {th }}$ grade pupils attending special schools for children with HI towards P.E. lessons.

The results of current study show mostly positive emotions towards P.E. lessons in pupils receiving special education when $19.2 \%$ are feeling at the P.E. always good and $38.4 \%$ of them mostly good. Authors Bendíková \& Nemček (2017) in their scientific paper presented even higher level of positive feelings during P.E. classes in the group of pupils living in orphanage, since $48 \%$ pupils of their study felt during the P.E. always good and $20 \%$ mostly good comparing our results. Another investigation show that pupils with visual disabilities expressed having significantly higher evaluation of their feelings comparing pupils who are D/HH (Kurková, Nemček \& Labudová 2015). Results of current study also showing significant differences in emotions between two different special schools for children with HI, since pupils from special elementary school located in Hrdličkova Street expressed having a higher positive evaluation of their feelings. The results from the research among pupils in regular elementary schools done by Čillík (2012) show positive emotions in $70.6 \%$ of pupils, $25 \%$ pupils of his study displayed neutral attitudes and $4.4 \%$ of pupils presented negative emotions towards P.E. classes. Neutral emotions during P.E. lessons of our sample were 
expressed by higher number of pupils $(31.5 \%)$ than in pupils of regular elementary schools $(25 \%)$.

The results of current study show statistically significant difference $(p<.05)$ in the emotions towards P.E. expressed by pupils' feeling at the P.E. lessons from the point of view of the respondents' gender, since boys expressed having significantly higher positive evaluation of their feelings. Significant difference $(\mathrm{p}<.01)$ in the emotions towards P.E. between genders was also presented in research chapter of Čillík (2012) where again boys attending regular elementary schools displayed significantly higher level of positive emotions comparing girls. Another research shows no significant differences in feelings and emotions towards P.E. lessons between boys and girls living in orphanage (Bendíková \& Nemček 2017).

The results of current study further show the highest level of indifference (50\%) in pupils receiving special education in the case that for some reason a regular P.E. lesson is cancelled. Similarly in the study of Kurková \& Nemček (2016) the group of pupils who are D/HH showed the highest level of indifference towards such a situation (59.5\%) out of all the pupils with disabilities involved in their research. We can argue that the content of P.E. classes at special schools is not exactly appropriate to pupils' interests and wishes therefor more than half of them do not care when the lesson is cancelled. Pupils of present study showed higher level of positive emotions if a P.E. lesson is cancelled. The results from the research among pupils in regular elementary schools done by Čillík (2012) show 30.4 \% of intact pupils who are happy if a regular P.E. lesson is cancelled. Compared to our findings, more pupils attending special elementary schools are happy (38.9\%) compared to intact pupils. This percentage is best approximated by pupils with physical disabilities $(38.6 \%)$ in the research of Kurková \& Nemček (2016). Another piece of research in regular school pupils (Görner \& Starší 2001) revealed a smaller number of pupils who are happy if they cannot do exercise compared to the number of pupils who are happy if their lesson is cancelled. This was true only in pupils with visual impairments $(21.3 \%)$ in the scientific paper of Kurková \& Nemček (2016). Results of Bendíková \& Nemček (2017) discovered that only 4 \% of orphan students were displayed negative emotion towards P.E.lesson when for some reason is P.E. cancelled.

In the present study did not occur significant differences between boys and girls neither between special schools with regards to their emotions in the case that for some reason a regular P.E. lesson is cancelled. Similar results presented Nemček's study (2017) which did not confirm significant differences between boys and girls living in orphanage. Even that, 
happier group in her study was presented by orphan girls, who were always happy $(35.7 \%)$ or happy very often $(21.4 \%)$ if a P.E. lesson is cancelled comparing orphan boys, who were always happy or happy very often if a P.E. lesson is cancelled in $37.2 \%$. Čillík (2012) found the emotionality in the case that for some reason a regular P.E. lesson is cancelled between boys and girls of regular elementary schools significantly different $(\mathrm{p}<.01)$. Boys of his research expressed higher level of negative emotions $54.5 \%$; $24.9 \%$ showed indifferent attitude and $20.6 \%$ displayed positive emotion. Girls of his study showed in $31.3 \%$ negative emotion if P.E. lesson is cancelled, $28 \%$ of them presented indifferent attitude and $40.8 \%$ were mostly happy or always happy if P.E. lesson was cancelled. Even differences between boys and girls of present study were not significant, higher degree of negative emotions to a cancelled P.E. lesson was also declared by boys as in previous mentioned research comparing girls attending special elementary schools.

The reason for some discovered differences in expressed emotionality comparison between pupils with $\mathrm{HI}$ and intact pupils may lie in the fact that pupils with sensory disabilities generally show less locomotion and space orientation and are able to perform only limited independent movement in space (Butterfield, van der Mars, \& Chase 1993; Longmuir \& Bar-Or 2000). Neglecting the health-oriented physical activities that are integral parts of the P.E. curriculum in schools for the pupils with sensory disabilities may also lead to poor posture or overweight in adulthood (Bendíková 2016a; Bendíková 2016b). Those findings in those pupils have also been mentioned in several other studies (e.g. Dair, Ellis \& Lieberman 2006; Prechtl et al. 2001).

The results of current study show higher level of positive emotions towards P.E. classes in pupils attending special elementary schools for children with HI. On one hand pupils show very high positive emotions of feeling during P.E. lesson on the other hand they are happier than upset since P.E. class is cancelled. The fact is, that the pupils do not want to practice even they generally have a positive relation towards P.E. lessons. There is a lack of the real positive relation towards regular long-term sport and physical activity (Labudová, Nemček \& Kraček 2015; Bendíková \& Dobay 2017).

By comparing the average values of the feelings during P.E. lessons provided by our pupils receiving special education (2.37 of the point score) with pupils who are D/HH (2.14 of the point score) and pupils with visual disabilities (1.52 of the point score) of Kurková, Nemček \& Labudová (2015) research as well as with pupils with physical disabilities (1.90 of the point score) of Nemček \& Bergendiová (2013) study and orphan students (1.84 of the point score), the highest level of positive emotions towards P.E. was stated by pupils with 
visual disabilities as opposed to all above mentioned pupils and students attending special schools in Slovakia. Interestingly lowest level of positive emotions towards P.E. lessons was expressed by pupils of our sample. When comparing the average values of responses about reaction when P.E. lesson is cancelled by pupils attending special elementary schools for children with HI (2.597 of the point score), and students living in orphanage (Nemček 2017) (2.6 point of the total score) interestingly we found out the same level of emotionality.

\section{Limits of study}

The results cannot be generalized, they only attest two special schools within the given region. This study was limited due to the low number of participating schools and the number of pupils, as well as due to the lack of knowledge of the level of current fitness and overall health condition of the pupils under this study.

\section{Conclusion}

Comparing the emotions and feelings of pupils attending special schools for children with HI shows significantly higher level of positive emotions only in feelings during P.E. lessons, where boys and those attending special school at Hrdličkova Street presenting significantly higher level of positive emotions. The statistically significant differences weren't discovered in the reactions when P.E. lesson is cancelled from the point of view of the gender neither schools.

The degree of emotions towards P.E. lessons is often related to the level of a pupil's successful gaining of movement skills, the level of intensity of specific exercises and their degree of difficulty, all which affect the pupil's ability to display their personality. Very often children attending special schools probably do not realize that regular participation in sports activities can help them to improve the quality of their life, especially in the field of selfservice activities, as well in all daily routine activities, which brings them, when they get older, more independence from other people, and later provides even more opportunities for inclusion through work activities despite their serious disability. When accepting the specific requirements of physical activities for pupils with $\mathrm{HI}$, we recommend that teachers at special schools create a space allowing pupils to utilise their individual skills and abilities to the maximum by performing activities according to their interests and wishes. This will increase the positive emotions of this mandatory subject and allow physical activities to become a 
regular part of pupils' leisure activities as well as long term physical activity in late adulthood.

\section{Acknowledgement}

The scientific paper was supported by grant projects VEGA 1/0726/17 with the topic "Sports motivational profile for different groups of population and the influence of various sport activity to improve the subjective dimension of quality of life"

\section{References}

1. ANTALA, B. \& J. LABUDOVÁ, 2008. Koncepcia učebných osnov telesnej a športovej výchovy pre ISCED 3. [The conception of P.E. curricula of ISCED 3]. In: Telesná výchova a šport, zdravie a pohyb [Physical Education and Sport, Health and Movement]. Prešov: MPC Bratislava, elokované pracovisko Prešov, pp. 17-25.

2. ANTALA, B., J. ŠIMONEK, I. ČILLÍK, J. LABUDOVÁ et al., 2012. Telesná a športová výchova v názoroch žiakov základných a stredných škôl [Physical and sports education as reflected in opinions of students of the elementary and secondary schools]. Bratislava, Slovakia: End.

3. BARTÍK, P., 2009. Postoje žiakov základných škôl k telesnej výchove a športu a úroven̆ ich teoretických vedomostí $z$ telesnej výchovy $v$ intenciách vzdelávacieho štandardu [Attitudes of elementary school pupils towards physical education and the level of their theretical knowledge in intention of educational standards]. Banská Bystrica: FHV UMB.

4. BENDÍKOVÁ, E., 2014. Lifestyle, physical and sports education and health benefits of physical activity. In: European researcher, 69(2-2), pp. 343-348.

5. BENDÍKOVÁ, E., 2016a. Changes in the posture of students due to equipment-aided exercise programs that are applied in physical and sport education. In: Journal of Physical Education and Sport, 16(2), pp. 281-286.

6. BENDÍKOVÁ, E., 2016b. Curricular Transformation of Education in the Field of Physical and Sport Education in Slovakia. In: European Journal of Contemporary Education, 18(4), pp. 410-417.

7. BENDÍKOVÁ, E. \& B. DOBAY, 2017. Physical and Sport Education as a Tool for Development of a Positive Attitude Toward Health and Physical Activity in Adulthood. In: European Journal of Contemporary Education, 6(1), pp. 14-21. 
8. BENDÍKOVÁ, E. \& D. NEMČEK, 2017. Attitudes and preferences of children living in orphanage towards physical education lessons. In: European Journal of Contemporary Education, 6(4), pp. 664-673.

9. BIDDLE, S.J.H., T. GORELY \& D.J. STENSEL, 2004. Health-enhancing physical activity and sedentary behaviour in children and adolescents. In: Journal of Sports Sciences, 22, pp. 679-701.

10. BUTTERFIELD, S. A., H. VAN DER MARS \& J. CHASE, 1993. Fundamental motor skill performances of deaf and hearing children ages 3 to 8. In: Clinical Kinesiology, 47(1), pp. 2-6.

11. ČILLÍK, I., 2012. Emocionalita hodín telesnej a športovej výchovy. [Emotionality in PE lessons]. In: B. ANTALA et al. Telesná a športová výchova v názoroch žiakov základných a stredných škôl [Physical and sports education as reflected in opinions of pupils and students of the elementary and secondary schools]. (pp. 49-64). Bratislava, Slovakia: End.

12. DAIR, J., K. ELLIS \& L.J. LIEBERMAN, 2006. Prevalence of overweight among deaf children. In: American Annals of the Deaf, 151(3), pp. 318-326.

13. DIGELIDIS, N., A. PAPAIOANNOU, K. LAPARIDIS \& T. CHRISTODOULIDIS, 2003. A one-year intervention in 7 th grade physical education classes aiming to change motivational climate and attitudes towards exercise. In: Psychology of Sport and Exercise, 4, pp. 195-210.

14. GERHATOVÁ, B., 2001. Školská telesná výchova v Národnom programe rozvoja športu. [School physical education in the National programme of sports development]. In: Perspektívy školskej telesnej výchovy a športu pre všetkých v Slovenskej republike (pp. 43-48). In: [Perspectives of the school physical education and sports for all in the Slovak Republic]. Bratislava: SVS TVŠ.

15. GÖRNER, K. \& J. STARŠÍ, 2001. Postoje, vedomosti a názory žiakov na II. stupni ZŠ na telesnú výchovu [Attitudes, knowledge and opinions towards physical education of secondary schol students]. Banská Bystrica: FHV UMB.

16. KURKOVÁ, P., 2010. Vzděláváni žáků se sluchovým postižením z hlediska vedení ke zdravému životnímu stylu. [The education of pupils who are deaf or hard of hearing from guiding to healthy life style point of view]. Olomouc: Palacky University. ISBN 978-80244-2582-5. 
17. KURKOVÁ, P. \& D. NEMČEK, 2016. Attitudes of students with disabilities towards physical education lessons: reasons for their indifference and preference for leisure time activities. In: Journal of Physical Education and Sport, 16(1), pp. 222-229.

18. KURKOVÁ, P., D. NEMČEK \& J. LABUDOVÁ, 2015. Pupils with sensory disabilities in physical education classes: attitudes and preferences. In: Acta Universitatis Palackianae Olomucensis. Gymnica, 45(3), pp. 139-145.

19. LABUDOVÁ, J., J. NEMČEK \& S. KRAČEK, 2015. Šport na každý deň. [Sport for everyday]. Bratislava: END spol.s.r.o. ISBN 978-80-89324-16-3.

20. LONGMUIR, P. E. \& O. BAR-OR, 2000. Factors influencing the physical activity levels of youths with physical and sensory disabilities. In: Adapted Physical Activity Quarterly, 17(1), pp. 40-53.

21. NAGYOVÁ, L., 1995. Determinovanost' účasti mládeže a dospelých na telovýchovných aktivitách [Determinants of participation of youth and adults towards physical and sport activities]. In: J. BARTIŠÍK, K. FÉLIX, L. NAGYOVÁ (Eds.). Štúdie I. Telesná výchova [Study I. Physical Education] (pp.103-108). Nitra: UKF.

22. NEMČEK, D. \& F. BERGENDIOVÁ, 2013. Oblúbenost' telesnej výchovy žiakov s telesným postihnutím. [The popularity of P.E. lessons in students with physical disabilities]. In: Telesná výchova a šport [Physical Education and Sport], 23(2), pp. 2-6.

23. NEMČEK, D., 2017. Attitudes and reasons for indifference of children living in orphanage towards physical education lessons. In: International Journal of Physical Education, Sports and Health, 4(5), pp. 161-165.

24. NOVOTNÁ, N., S. KARIKOVÁ \& N. VLADOVIČOVÁ, 2007. Postoje žiakov mladšieho školského veku k telesnej výchove. [Attitudes of younger school age pupils towards physical education]. In: J. LABUDOVÁ et al. (Eds.). Tvorba kurikula telesnej výchovy v rámci transformácie vzdelávania vSlovenskej republike. (pp. 111-117). Bratislava: UK FTVŠ.

25. PARDEL, T. \& J. BOROŠ, 1979. Základy všeobecnej psychológie. [The Basics of General Psychology]. Bratislava: SPN.

26. ROBAZZA, C., L. BORTOLI, A. CARRARO \& M. BERTOLLO, 2006. “I wouldn't do it; it looks dangerous'": Changing students' attitudes and emotions in physical education. In: Personality and Individual Differences, 41, pp. 767-777.

27. PRECHTL, H. F., G. CIONI, CH. EINSPIELER, A.F. BOS \& F. FERRARI, 2001. Role of vision on early motor development: lessons from the blind. In: Developmental Medicine \& Child Neurology, 43(3), pp. 198-201. 
28. SMOLEŇÁKOVÁ, N. \& E. BENDÍKOVÁ, 2017. Effect of the Content Standard for Changing the Level of Knowledge of Secondary School Students. In: Journal of Physical Education and Sport, 17(1), pp. 182-187.

29. SPRAY, C.M., S.J.H. BIDDLE \& K.R. FOX, 1999. Achievement goals, beliefs about the causes of success and reported emotion in post-16 physical education. In: Journal of Sports Sciences, 17, pp. 213-219.

30. SÝKORA, F., 1988. Podiel školskej telesnej výchovy na zabezpečení všestranného vývinu mládeže. [Part of physical education to ensure overall development of youth]. In: Telesná Výchova Mládeže, 54(8), pp. 297-302. 